Muller, KS, Jansen van Rensburg, MS \& Makobe, $M K$

\title{
THE EXPERIENCE OF SUCCESSFUL TRANSITION FROM A CHILDREN'S HOME TO INDEPENDENT LIVING
}

Mr Karl S. Muller is a Research Psychologist. He is currently Research Coordinator for SOS Children's Villages (South Africa).

Ms Madri S. Jansen van Rensburg is a Research Psychologist. She is currently the Research Manager for People against Women Abuse (POWA).

Ms MK Makobe is Research Psychologist. She is currently a Junior Lecturer in the Department of Psychology at the University of South Africa.

\section{INTRODUCTION}

The research explores the experience of growing up in a children's home, as well as the experience of having to make a transition from a children's home to society. It wants to know from individuals who have lived this experience, what they believe aided them in attaining success and what has hindered their strivings. In consultation with SOS Children's Villages, the researchers chose to follow a positive ethos similar to Cooperrider's Appreciative Inquiry (Hammond, 1996). Appreciative inquiry is a theory of organisational change that focuses on "what works" rather than traditional "what is broken" models of problem solving (Hammond, 1996). The underlying assumptions of appreciative inquiry are (1) "in every society, organisation or group, something works" and (2) "what we focus on becomes our reality" (Hammond, 1996:4). Consequently, the present research is aimed at learning, "what works" from the experience of those that have grown up in their villages.

\section{THE SOS ORGANISATION}

As all the participants were raised in an SOS Children's Village, the research, it is also implicitly exploring SOS's guiding principles of their approach to foster care. Thus, a brief exposition of the organisation is relevant. SOS-Kinderdorf International is a private, nondenominational organisation that aims to aid orphaned, abandoned and destitute children (SOS brochure, 1996). SOS provides these children with as stable and permanent a home as possible.

The main programme run by SOS-Kinderdorf International is SOS Children's Villages. The village consists of a number of homes, within which 6 to 10 children are placed to best copy the sibling pattern in a family of that size. An SOS Mother runs each household and cares for the children within it permanently. The children placed in a home are encouraged to see each other as brothers and sisters. At an appropriate age, and in consultation with the child, he or she will move from his or her SOS home to a youth house. Here he or she will practise semiindependent living in preparation for independence.

In essence, the SOS approach to foster care is based on the following four principles (SOS brochure, 1996):

1. The mother: children are placed with a woman who raises them as a mother.

2. Brothers and sisters: non-related children placed in a home are raised as siblings. Biological siblings are not separated.

3. The house: each SOS family has its own house, in which they live independently as a family. 
4. The village: which forms a community in which the child socialises according to the culture appropriate to that child.

At present there are 439 villages in 131 countries, housing approximately 43000 children (SOS-Kinderdorf International, Facts and Figures, 2003).

\section{LITERATURE REVIEW}

Whereas "successful transition" is a broad concept, its initial operationalisation is delimited by what is organisationally defined as success. According to the SOS Children's Villages (South Africa) organisation success is defined as:

The ability of an ex-SOS child to integrate back into the community and live a life independent of SOS material support within an acceptable legal frame (Moteetee, 2001).

According to the organisation, successful "SOS Adults" are integrated into the community they choose to live in, are financially independent and their financial independence is legally obtained i.e. not through criminal activity. These criteria were then also used to select the participants in this study.

Financial success as an economic focus is, in general, defined as the quantity of materials (possessions, financial security etc) one can acquire (Mathite, 2000). However, the successful psychological transition to an independent life implies positive personal experience. This may include feelings of satisfaction, self-development and personal worth (Stober \& Schumacher, 1972).

According to Erikson's (1964) psychosocial approach to human development, the final progression towards independent takes place during adolescence and early adulthood. Adolescence is characterised by feelings of confusion because the adolescent is experiencing both physical and psychological changes (Louw, Van Ede \& Louw, 1998). The adolescent is no longer a child but not yet an adult. To become an adult, Erikson believes that individuals at this age need to establish an identity (Louw et al., 1998). Erikson named this stage "identity versus role confusion" (Louw et al., 1998:160).

The identity versus role confusion stage starts with the onset of puberty, at about twelve, and ends with the beginning of maturity. During this stage, an individual acquires a sense of identity when he or she manages to integrate all his or her earlier identifications, drives, wishes, expectations, abilities and skills, with the opportunities society offers him or her (Erikson, 1964).

The establishment of a well-defined sense of self requires emotional, physical, moral and financial support. Parents and the community usually provide this support. Aldgate, Maluccio and Reeves (1989:89) found that "...stable affectional bonds between parenting figures and children throughout childhood contribute to the well-being of both parents and children".

In an institutional children's home setting, staff members become part of a young person's network if they stay in the home for a long time (Whitaker, Archer \& Hicks, 1998). The young person may relate best to the unit manager, or find his or her favourite member[s] of staff, who then becomes special. As closeness develops, and residential workers take on parental roles and responsibilities, the relationship between staff members and individual young people moves from "formal" to the more personal (Whitaker et al., 1998). Thus, children's homes should also provide adult figures that may come to be regarded as "significant others" by the 
children. The term "significant" here denotes (1) those persons who exercise a major influence on the attitude of individuals by communicating the norms, values and expectations of the culture or society in which they live; (2) define behaviour that is considered to be appropriate to the culture or society of an individual; and (3) model attitudes and behaviours appropriate to that culture or society (Woefel \& Haller, cited in Shade, 1983). In the SOS approach to foster care the mother-figure is especially important, because her through permanence and care giving role she serves as a key "significant other" for the children.

In non-institutional residential home environments, the role of the father is considered important. Closeness with a father can be especially important in fostering a child's sense of self-esteem and self-confidence (Biller, 1993). Whereas the SOS approach does not have an explicit place for a foster father, each village strives to provide several male role models in the form of drivers, handymen, youth leaders, administrators, etc (SOS Brochure, 1996). The principle "father figure" of the village is the village director (SOS Brochure, 1996).

In the absence of a father, boys may act in a masculine way in some facets of their behaviour, while behaving in masculine or in feminine ways in other situations (Lamb \& Sagi, 1983). This may indicate identity confusion (Lamb \& Sagi, 1983). Identity confusion is the opposite of the Eriksonian goal of adolescence, which is establishing a stable identity. Girls who do not have the opportunity to observe their mothers interacting with their fathers may not learn how a wife is supposed to relate to her husband (Lamb \& Sage, 1983). This could play a role in young girls rejecting the role of being a wife or a mother and they may feel insecure in their basic femininity (Lamb \& Sagi, 1983). However, not all children are affected negatively by the absence of a father figure (Price \& McKenry, 1988). Some may continue to show self-esteem and self-motivation, may feel challenged by their environment and continue to do well and progress well in life like children raised by with both parents (Magrab, cited in Price \& McKenry, 1988).

Graber and Brooks-Gunn (1990) note that a primary transition for adolescents toward becoming independent adults, in a non-institutional residential home environment, is leaving the parental home. The success of an adolescent's transition toward adulthood is defined by the assumption of a range of adult roles. A comparison of orphaned people and those from "normal" home circumstances indicated that there were equal proportions of professionals, skilled workers and unskilled workers (McKenzi, 1998). Thus, an orphan is as capable of making this transition as any other adolescent is.

Social context provides for a basis for learning skills and strategies to cope with major developmental tasks, as well as attributional beliefs for the future (Nurmi, 1989). Both the SOS house and SOS village are social contexts for the adolescents. A unique feature of the SOS house and village is that children are encouraged to think of each other as family, or brothers and sisters. The children will form lengthy permanent relationships with other (non-related) children in the house and under the care of a particular SOS mother. According to Cotterell (1996), a sibling relationship functions as a miniature social environment, where the difference in age plays a less important role as children get older. A corresponding decrease in the aspects of dominance and antagonism occurs in the relationships as the siblings get older. Aldgate $e t$ al. (1989) are of the opinion that adolescents in care require the same opportunities for making successful transitions into adulthood. These opportunities include family/social support. The creation of a new "family" will surely impact on the lives of the children as they develop a new social context. 
The developing child needs the presence and participation of other parties such as relatives, friends and neighbours to deal with the environment effectively (Bronfenbrenner, 1979). A lack of such support will have deleterious consequences for a person and Raychaba (1988) believes that youth in a foster care setting are more disturbed now than in the past because of less thoughtful provision to their social needs, such as family and social support. SOS Children's Villages attempt to achieve this participation by encouraging children, in the same family unit, to think of each other as brothers and sisters. This participation is further encouraged by the role of the SOS village providing a sense of community that allows for a learning of cultural or shared realities for the growing child with his or her siblings.

Given this approach to foster care the goal of this study is to gain some insight into the experienced realities of some SOS foster care persons who have successfully formed an independent and self-sustaining life.

\section{METHOD}

Mordock (1994) calls for the application of qualitative research in children's homes. As he points out all Children's homes aspire to help the children in their care attain an Eriksonian identity, i.e. to develop psychologically healthy individuals (Mordock, 1994). Therefore, research in children's homes needs to evaluate the ideas, and effectiveness, of a particular approach or programme toward this end. Qualitative methods eschewing of large randomised samples for a contextual and information rich sample means that each children's home can evaluate their ideas and programmes individually (Mordock, 1994). On a practical level it is often impossible for Children's homes to find a sample random or large enough to complete a viable quantitative inquiry (Mordock, 1994).

Present research questions include what is it like to grow up in a children 's home, and what does a person that grew up in a children's home go through, emotionally, when they make the transition from the home to society. The research is therefore located in the individual's perception [s] of [lived] experience. These perceptions of lived experience will give us an insight into the participants' journey towards being psychologically healthy individuals. Thus, this research uses qualitative methods, because it strives to gain knowledge "from within the context and perspective of human experience." (Kelly, cited in Rapmund, 2000:126, last emphasis added). This is based on the assumption that one can only comprehend experience from "people's subjective interpretations or accounts" (Rapmund, 2000:126). The specific method used is that of collective case studies (Stake, 1994).

\section{The Collective Case Study}

Lindegger (1999) states that case studies are defined as an ideographic research method, that is, methods that study individuals as individuals rather than as members of a population. Whereas, case studies are suited to qualitative research, the question now arises whether the subject matter of the current research lends itself to qualitative case studies as a vehicle for this research?

Very little research has been undertaken into the life experiences of individuals that have grown up in childcare institutions, such as orphanages or children's homes, (Bullock, Little \& Millham, 1993). Seethal (2001) has studied life outcomes of SOS Children. Her study included the village from which the current cases are drawn. These life outcomes include such factors as general living conditions, schooling situation, employment situation, and marital status (Seethal, 2001). In contrast to this biographical approach, whose aim is to quantify life 
outcomes, such as employed vs. unemployed, the present research seeks to understand how financially independent black adults who grew up in an SOS village experienced their upbringing. Other research done in SOS facilities include Dumaret (1988), who studied SOS children's scholastic achievement in France and Grundlingh (1991), who examined support systems for SOS mothers in an SOS Village. Each of these has a peripheral impact on the current topic.

Given the multiplicity of experience and the emic nature of qualitative research, (Fetterman, 1998), one requires a research method that allows for the analysis of each case individually as well as comparison across cases. Stake (1994:236) describes such a mechanism, which he calls a "collective case study." Collective case studies is useful when research needs to qualitatively explore a social phenomenon. The researcher draws several cases and studies them for similarities and differences.

\section{Data Gathering}

Data were gathered using open-ended interviews. Following the primary aim of the research, the interview schedule was designed to explore aspects of growing up in a SOS village that served to promote or constrain a successful independent life.

The areas explored included what the respondents viewed as success (How would you define success?), how successful they believe their lives have been (Where in your life do you feel that you have been successful?), why they have been successful in some areas (Why do you think that you have been successful in these areas?) and how SOS contributed or constrained their success (How do you feel that the SOS youth home contributed to your success, How do you feel that the SOS youth home did not help, or hindered, your success?). There were also questions dealing with how respondents would change the village or factors outside the SOS system, as to aid them to achieve success.

\section{Data Analysis}

The data was analysed using a process similar to Schneider's (1991) exploration of depression. Each interview was transcribed. Separately, the first and second authors repetitively read the transcripts to discover recurring areas discussed, topics mentioned, emotional experiences and perceptions. Each of the topics was grouped into categories. The two authors then reached consensus about the categories. Then the three authors, together, examined the categories for similarities in meaning. Where categories were similar, they were refined as themes. These themes were then examined using existing psychological literature and the authors' own synthesis of the presented themes. The themes are grounded, for the reader, with quoted examples of the participants and responses during the interviews (Stiles, 1993).

\section{DESCRIPTION OF PARTICIPANTS}

A brief biographical description of the three participants follows (all names have been changed to ensure confidentiality):

Anna is 28. She entered SOS at age 14. She was placed there because her mother was unable to care for her due to a disability. Anna stayed in the village for 5 years and at age 19 moved to the youth house. Anna was a member of the first group of youth in the village. She remained in the youth house for 2 years. She has Diplomas in Personal Computing, Office Computing and Bookkeeping and a Certificate in Public Relations. She is currently working as a receptionist 
for a market research company and has opened her own restaurant and catering business in Mamelodi. She has a daughter of six and is expecting her second child. She is engaged.

Brent is 27 . He entered SOS at age 12 after his parents separated and were no longer able to care for him. He stayed in the village for 5 years and in the youth house for another 5 years. He was also a member of the first group of youth in the village. He has matric (Grade 12) and is currently employed as a travel consultant by a travel agency. Brent is single and has no children.

Charles is 23 . He entered SOS at age 9 after his parents passed away and his biological family were unable to care for him. He stayed in the village for 11 years and in the youth house for $2 \frac{1 / 2}{2}$ years. Anna is his older "SOS sister" and he considers her his true sister. He has a Certificate in Marketing and Business Management and is currently working at the computer centre at the village. He too is single and has no children.

All three participants grew up in the same SOS Village, which is located in a township South East of Pretoria. All three experienced township life during the turmoil of the liberation struggle. During her interview Anna made mention of having to leave a previous foster mother due to political instability. Therefore, as a group the participants, have had to deal with social injustice, in the form of apartheid laws, as a part of the socio-cultural reality.

\section{RESULTS AND DISCUSSION}

The themes described here are enmeshed. They do not stand in isolation. Rather, the participants experience all the themes as integrated parts of their lives. They are separated here to enhance an initial understanding of their experience. The researchers encountered some overlap between themes and several themes tend to "lead on" from previous ones. Finally, the order of the themes is in no way hierarchical. No one theme is more important that the others.

\section{Being a role-model}

All the participants equate success with being seen as a role model. Anna stated that financial success is important to her. However, this was directed towards caring for her daughter and not having wealth for herself. From Maslow's (1970, cited in Moore, 1989) hierarchy of needs, success in this context could be regarded as focusing on meeting the need for esteem and appreciation. Jordaan and Jordaan (1998) are of the opinion that the need for esteem and appreciation implies being recognised as having human dignity.

How is this related to Anna's expression that orphans "love too much"? One implication is that these three individuals have taken this desire and turned it into positive action, rather than being caught in burdensome relationships, such as the one experienced by Anna (she was rejected by the father of her first child). They may be fulfilling their need for esteem by helping others. More research is necessary to explore this question.

\section{Goal Orientated}

All three regard success as something they are yet to reach. Anna states that there is still a "pot of gold" waiting for her and both Brent and Charles said that they yet have more to achieve. Brent says, "I always knew what I wanted in life...". Anna's specific goals are to make a success of her restaurant and be financially independent. Charles' goals are to get a better job and have a family. He says that he started talking to his SOS mother about this from an early age. Brent is not specific about his goals but does explicitly state that he has more to achieve. 
He says, "I still want more out of life...". All three participants are goal orientated and highly motivated to achieve these goals.

Several theorists have studied the motivational qualities of goals. Locke and Latham (1990, cited in Baron \& Byrne, 1994) looked at setting goals as motivation in a work setting. Argyle (1988:230) states the "...motivational basis of relationships can be explored by analysing the goals...". In constrast, Gordon Allport (1961, cited in Meyer, 1989a) studied personal goals as a motivational force. All these theorists saw distinct goals as motivating people to achieve. Locke and Latham as improving productivity, Argyle as improving relationships and Allport as leading to optimal functioning. The views of these authors explain the highly motivated nature of the three participants. They have set goals for themselves and this motivates them towards success.

Success takes a slightly different form for all three participants. All three view recognition as role models as having achieved success. However, they also have unique goals. Anna wants financial security for her children, Brent seeks more out of life and Charles wants a family and a stable job. The theme here is not their goals per sé, but that having goals motivates them.

\section{Empathetic Caregivers}

All the participants, in their interviews, state that they loved their SOS mothers at least as much as they would have loved their biological mothers. Charles, for example, considers his SOS mother as his real mother and Anna mentions bonding with both her SOS mothers (she had two different mothers during her stay at SOS). The reason given for loving these women was that they were always patient, ready to listen, and give advice when asked. At one point, during the interview, David laughingly states he was very naughty when he entered the village, but his SOS mother was very patient and he grew to respect and appreciate that. These women all exhibited empathy.

Baron and Byrne (1994:418) define empathy as “...responding to another person's emotional state with a vicarious emotional reaction that resembles what the other person is experiencing." It involves feelings of sympathy and compassion (Betancourt, 1990). Empathy is key in building satisfying relationships (Fromm, 1976), prosocial behaviour (Eisenberg \& Fabes, 1991) and is related to altruism (Batson, Duncan, Ackerman, Buckley \& Birch, 1981). The emotional well-being of children in a children's home is enhanced by the willingness of staff members to listen empathetically (Sinclair \& Gibbs 1998).

As the SOS mother is the primary caregiver in the SOS approach to foster care it stands to reason that she needs to show a great deal of empathy with her "children." Research in SOS Villages in France shows the importance of the SOS mother. Dumaret (1988) found that the SOS mother had an important role to play for both the educational and emotional development of the child. This was related to the fact that they not only fulfilled the children's basic needs for shelter and food but also encouraged them to excel, and listened to them. Grundlingh (1991) believes that improved support for SOS mothers will help them be more effective caregivers.

The three participants considered that they received unconditional love and acceptance from their SOS mothers. They argued that they have built their other relationships on these experiences of love and acceptance. It is therefore important that the feeling of being loved and unconditionally accepted by their SOS mother is explored. This emphasises the importance of sensitivity and responsive listening by the SOS mother. 
This need for an empathetic listener is especially important in the youth house because none of the participant experienced the SOS youth house system as unconditionally accepting. Rather, they felt the youth house system was counting their mistakes before "expelling" them. It is common for children in children's homes to feel powerless and controlled by the "system" (Fisher, Marsh, Phillips \& Sainsbury, 1986). However, the perceived rigidity of the SOS system only seems to become apparent at the youth house level. This is where the participants expressed that they encountered difficulties with rules and regulations. Anna and Brent were specific in their criticism of the rules, both mentioning that they were not given a chance to state their cases in disciplinary hearings and that they felt that they had no one, amongst the Youth Leaders, to talk about their problems to. The presence of an empathetic and listening caregiver often does much to alleviate this situation (Sinclair \& Gibbs, 1998). This implies that Youth Leaders need training in empathetic listening as they now fill the role of caregiver. Indeed all three participants stressed that some sort of counselling training was necessary for Youth Leaders.

\section{Attachment}

Louw et al. (1998:212, emphasis added) state that, "Attachment refers to the emotional bonding that takes place between two individuals, usually between a child and mother or primary caregiver." The previous theme showed that the three participants loved their SOS mothers. Anna states that she bonded with her mother, Brent wants to help his SOS family and Charles considers his SOS mother as his real mother. He adds to this by saying that he misses her now that she has retired and is living in Umtata. Thus, they have formed an attachment with their SOS mothers. Aldgate et al. (1989) found that stable bonds between caregivers and children contributes to the well-being of both.

Of import here are the negative consequences that staff turnover has for attachment. Berridge and Brodie (1998) showed that low staff turnover in children's homes produced higher quality care. It is clear how difficult it can be for a child to rebuild a trusting relationship with another primary caregiver in Anna's statements: "I was lucky I only had two moms [SOS mothers]...my first one I loved her. We bonded...but when she was chased away out of SOS, I had to accept another mom. I'm not a robot ... I can't just absorb and say it's a new mom...you are bitter." In its history, the SOS Village the participants were raised in has experienced a fair rate of staff turnover, not only of mothers, but social workers, admin staff and youth leaders as well. This may mirror the process of transiency in the foster care system (Raychaba, 1988). Transiency is the process of a child being moved repeated from one foster home to another (Raychaba, 1988). This process carries with it a cycle of leaving and readjustment, or put another way a cycle of abandonment and re-attachment. The psychological effects of transiency include; inadequacy in making and maintaining relationships, lack of trust, feeling "different" to others and a fear of showing affection (Bagley, cited in Raychaba, 1988). Note that Anna explicitly states. “...we [SOS Children] think differently from children who have their own parents." In fact, many children will have experienced this before entering SOS. Children placed in SOS will often have moved through several foster homes or places of safety before being placed in SOS. Staff turnover then repeats the cycle of abandonment in the lives of the children and its effects are surely similar to that of transciency in foster children. This can be seen in Anna's description of the effects of her mother being "chased away." This aspect requires further investigation.

The theme of attachment also reflects the importance of the theme of empathetic caregivers. Berger (1994) showed that attachment formation is easier for children that are adopted as 
babies. Seethal (2001) found that children's average age of admission to SOS was 10 years. Children at this age have already passed through several crucial developmental stages. Erikson (1963, cited in Meyer, 1989b:159) believes, that 10 year old children are in the process of resolving their "initiative versus guilt" challenge. Most of these children have experienced transciency (Anna's story is a good example) in some form (either by moving through several foster parents or institutions before entering SOS or by having several mothers within SOS) and this will negatively impact on their resolving previous life stage challenges. Further, the children should also exhibit the negative consequences of transciency, such as being unable to start or continue relationships (Bagley, cited in Raychaba, 1988). These factors will complicate the process of forming an attachment. Thus, empathy is an essential quality in an SOS mother. She needs to be empathetic to form an attachment to the children in her care.

\section{Self-esteem}

All three the participants spoke confidently and evidenced a healthy self-esteem. Anna says, "I'm a wonderful woman - inside, you know." They have over-come the tendency for individuals with a history of abandonment and institutionalisation to have low self-esteem (Raychaba, 1988). It would be fruitful to explore how the participants achieved this, as low self-esteem is a risk factor in the lives of all SOS children. Sinclair and Gibbs (1998) offer one explanation. They found that the break away from their previous environment, afforded to children in a children's home, gave them an opportunity to change some aspects of their sense of self. This was achieved in several children's homes in Britain by setting standards for the children to maintain, challenging negative behaviour, encouraging self-esteem with positive reenforcement and giving them opportunities to experience success (Sinclair \& Gibbs, 1998).

Perseverance and hard work are recurring categories linked to the theme of self-esteem. Charles lives by his SOS mother's words, "Never let anything that does not talk beat you" so he will, “...keep pushing until I get what I want." Anna has persevered great challenges to attain an independent lifestyle. An example of this is her breastfeeding her baby while studying for her matric exams. Brent's comment "I always knew what I wanted..." is qualified by him saying, "...not so clever but hard working".

Baron and Byrne (1994:129) define attitudes as "...associations between attitude objects (virtually any aspects of the social world) and evaluations of those objects." A major driving force in the participants' journey to success is a constant quest to rise above their circumstances, i.e. perseverance. Attitudes and self-esteem are closely linked and self-esteem may be seen as containing attitudes about oneself (Baron \& Byrne, 1994). The link between the participant's attitude towards perseverance and their self-esteem may be characterised as follows. The participants see perseverance as a good quality. They evaluate it in a positive light. This motivates them to action, by persevering in difficult circumstances. This, in turn, leads to a rise in self-esteem because they are doing something they feel is good.

\section{Family Relationships}

In general, youth that were raised in children's homes regard work, good behaviour and family as valuable and important because they contribute to an integrated sense of self (Sinclair \& Gibbs, 1998). Their providing housing for biological family members expresses the importance of family in the lives of the three participants. Both Anna and Brent have built houses for their biological family while staying elsewhere, while Charles houses his biological brother in his flat. Relationships, or contact, with biological family members provides a sense of identity and reintegration with family systems (Sinclair \& Gibbs, 1998). Reintegration with family in this 
study could be regarded as an emotional bond that the participants keep with their biological family even if they are not staying at their original homes.

This positive attitude towards maintaining family ties also extends to their SOS families. They want to reciprocate that which they felt they had received in SOS. For example, Brent is currently coaching the village soccer team and Anna financially aids other individuals that were raised in the village with her. This supports Raychaba (1988) who found that interrelationship skills, which include marriage management, parenting skills and information on basic matters of sexuality, could be effectively provided in care homes.

The participants expressed strong views about having a family of their own. They often stated that they did not want to repeat mistakes made in their lives with their children. They strive to provide a better financial situation for their own families. As Brent refers to his biological family, "Nothing I can change now, but I can improve on my own family."

\section{Responsibility}

Leading from the previous theme it is important to all the participants to accept, and deal with, responsibility. They expressed the feeling that fulfilling family commitments is part of the responsibility of a person leading a successful independent life. Learning responsibility was a challenge for all three participants. They all, at first, saw the youth house as an exciting opportunity to get away from the village. They were soon met by the responsibility of setting their own rules and punishment. Whitaker et al. (1998) state that giving children a "voice" in establishing rules and the consequences of breaking them is characteristic of good practice in a children's home. They found that this allows the youth to set their own boundaries, promotes responsibility and gives the children a feeling of being heard, or taken seriously. Although the participants were allowed input on the creation of rules, they still felt that they had no "voice" or power. Rather, they felt the rules were there to monitor and expel them. Fisher et al. (1986) confirm that arbitrary and inconsistent application of rules is deleterious to the development of children in children's homes. While rules need to be rigid enough to give structure, they should also be flexible enough to convey a caring attitude (Whitaker et al., 1998).

\section{Practical Skills}

Lack of basic skills is a risk factor for youth who grew up in care (Raychaba, 1988). Basic skills include, “...money management/budgeting skills, knowledge pertaining to locating and accessing appropriate accommodation, basic household living and knowledge concerning access to medical care coverage" (Raychaba, 1988:44). All participants stated that their budgeting skills and the ability to find tertiary education assistance were limited when they entered the Youth house. Raychaba (1988) further states that youth from foster care settings generally undergo a greater financial burden than youth from general biological family units because, they must assume the full cost of providing themselves with the material "basics" of independent life. This is especially evident during the initial phases of their exodus from the security afforded by the foster care system. This seems to be confirmed by the present study as all participants mentioned struggling financially at the beginning of their stay in the youth House. However all three learned to live and plan with limited resources and budgets available to them. Their struggle to attain this skill has laid the foundation for the financial independence that they presently have. 


\section{POSSIBLE FUTURE RESEARCH}

What follows are general areas that need exploration. Firstly, this study should be repeated with individuals that grew up in other childcare institutions and fall within that organisation's definition of successful societal integration. This will clarify or change the patterns that emerge in this study. Qualitative research is contextual; therefore repeating the study in other contexts will give each organisation a reflection of what its youth are experiencing. At the same time, the collective case study method allows for comparison across cases. Thus, a more comprehensive understanding of the experience of re-integration into society can be created. Secondly, the present research is retrospective and present SOS youth should be included in future research by assessing whether the themes that emerge in the present study are also relevant to a new generation.

\section{CONCLUSION}

This study has sought to elucidate an under-explored area of social need. There are literally thousands of children that need to make the adjustment from institutional life to society. With the spectre of the AIDS pandemic and the consequences this holds for increasing numbers of orphans in South Africa it seems imperative to explore and gain more grounded knowledge of successful foster care practices.

\section{REFERENCES}

AlDGATE, J.; MALUCCIO, A. \& REEVES, C. 1989. Adolescents in foster families. Chicago: Lyceum.

ARGYLE, M. 1988. Social relationships. In: HEWSTONE, M.; STROEBE, W.; CODOL, J. \& STEPHENSON, G.M. (eds), Introduction to social psychology: A European perspective. Oxford: Blackwell.

BARON, R.A. \& BYRNE, D. 1994. Social psychology: Understanding human interaction ( $7^{\text {th }}$ ed) Boston: Allyn \& Bacon.

BATSON, C.D.; DUNCAN, B.D.; ACKERMAN, P.; BUCKLEY, T. \& BIRCH, K. 1981. Is empathy emotion a source of altruistic motivation? Journal of Personality and Social Psychology, 40:290-302.

BERGER, K.S. 1994. The Developing Person throughout the Lifespan (3 ${ }^{\text {rd }}$ ed). New York: Worth.

BERRIDGE, D. \& BRODIE, I. 1998. Children's homes revisited. London : Jessica Kingsley.

BETANCOURT, H. 1990. An Attribution-Empathy Model of Helping Behavior: behavioural intentions and judgements of help-giving. Personality and Social Psychology Bulletin, 16:573-591.

BILLER, H.B. 1993. Father's and Families: paternal factors in childhood development. Westport: Auburn House.

BRONFENBRENNER, U. 1979. The ecology of human development. London: Harvard.

BULlOCK, R.; LITTLE, M. \& MILLHAM, S. 1993. Residential care for children: A review of the research. London: HMSO. 
COTTERELL, J. 1996. Social networks and social influences in adolescence. London: Routledge.

DUMARET, A. 1988. The SOS Children's Villages: school achievement of subjects reared in a permanent foster care (part two). Early Child Development and Care, 34:271-277.

EISENBERG, N. \& FABES, R.A. 1991. Prosocial behavior and empathy: A multimethod developmental perspective. In: CLARK, M.S. (ed) Prosocial behavior. Newbury: Sage, 3462.

ERIKSON, E. 1964. Childhood and Society. New York: W.W. Norton.

FETTERMAN, D.M. 1998. Ethnography: Step by step. (2 ${ }^{\text {nd }}$ ed) Thousand Oaks: Sage.

FISHER, M.; MARSH, P.; PHILLIPS, D. \& SAINSBURY, E. 1986. In and out of care: The experiences of children, parents and social workers. London: B.T. Batsford.

FROMM, E. 1976. To have or to be. London: Abacus.

GRABER, J.A. \& BROOKS-GUNN, J. 1990. Expectations for and precursors to leaving home. In: GRABER, J.A. \& DUBAS, J.S. (eds) Leaving home: Understanding the transition to adulthood. San Francisco: Jossey-Bass, 21-38.

GRUNDLINGH, A. 1991. 'n Kruiskulturele ondersoek na die behoefte duur en aard van 'n ondersteuningsisteem vir swart huismoeders binne 'n kinderhuisverband [A crosscultural investigation of the need for and nature of a support system for black housemothers in a Children's home context]. Pretoria: University of South Africa. (D.Lit.Phil. Thesis)

HAMMOND, S.A. 1996. The thin book of appreciative inquiry. Plano: Thin Book Publishing.

JORDAAN, W. \& JORDAAN, J. 1998. People in context. Johannesburg: Heinemann.

LAMB, M.E. \& SAGI, A. 1983. Fatherhood and family policy. New Jersey: Lawrence Earlbaum.

LINDEGGER, G. 1999. Research methods in clinical research. In: TERRE BLANCHE, M. \& DURRHEIM, K. (eds) Research in practice: Applied methods for the social sciences. Cape Town: University of Cape Town Press, 251-266.

MORDOCK, J.B. 1994. The search for an identity: A call for observational-inductive research methods in residential treatment. Residential treatment for children and youth, 12(1):1-23.

LOUW, D.A.; VAN EDE, D.M. \& LOUW, A.E. 1998. Human development. (2nd ed) Pretoria: Kagiso.

McKENZI, R.B. 1998. Rethinking Orphanages for the $21^{\text {st }}$ Century. Thousand Oaks: Sage.

MATHITI, V.I. 2000. An exploration study into quality of life of street children standard of living in Pretoria. Pretoria: University of Pretoria (M.A. thesis).

MEYER, W.F. 1989a. Gordon Allport's holistic theory. In: MEYER, W.F.; MOORE, C. \& VILJOEN, H.G. Personality theories: From Freud to Frankl. Johannesburg: Lexicon, 325354. 
MEYER, W.F. 1989b. Erik Erikson's Egopsychological Theory. In: MEYER, W.F.; MOORE, C. \& VILJOEN, H.G. Personality theories: From Freud to Frankl. Johannesburg: Lexicon, $145-166$.

MOORE, C. 1989. Abraham Maslow's self-actualisation theory. In: MEYER, W.; MOORE, C. \& VILJOEN, H.G. Personality theories: From Freud to Franlk. Johannesburg: Lexicon, $355-372$.

MOTEETEE, L. 2001. National Director. SOS Children's Villages (South Africa). Personal Communication, 1 April. Randburg.

NURMI, J. 1989. Adolescents' orientation to the future: Development of interests and plans and related attributions ad affects, in the life span context. Helsinki: Finnis Society of Science.

PRICE, S.J. \& McKENRY, P.C. 1988. Divorce. London: Sage.

RAPMUND, V.J. 2000. Enhancing student's personal resources through narrative. Pretoria: University of South Africa. (D.Lit. Phil. Thesis)

RAYCHABA, B. 1988. To be on our own with no direction from home: A report of the special needs of youth leaving the care of the child welfare system. Canada: Canadian Children's Foundation.

SCHNEIDER, C.K. 1991. Etiology and phenomenology of depression in women. Miami: Miami University. (PhD thesis)

SEETHAL, S. 2001. Report on Youth out of SOS Care. Randburg: SOS Children's Villages (Southern Africa region II), (unpublished research report).

SHADE, B.J. 1983. The social success of black youth: the impact of significant others. Journal of Black Studies, 14:137-150.

SINCLAIR, I. \& GIBBS, I. 1998. Children's homes: A study in diversity. Chichester: John Wiley \& Sons.

SOS BROCHURE 1996. Hermann Gmeiner - the SOS Children's Villages. Innsbruck: SOS-Kinderdorf - Verlag.

SOS KINDERDORF INTERNATIONAL 2001. Facts and Figures 2003. Innsbruck: SOS Kinderdorf - Verlag.

STAKE, R.E. 1994. Case Studies. In: DENZIN, N.K. \& LINCOLN, Y.S. (eds). Handbook of qualitative research. Thousand Oaks: Sage, 236-247.

STILES, W.B. 1993. Quality control in qualitative research. Clinical Psychology Review, 13(6):593-618.

STOBER, G.J. \& SHUMACHER, D. 1972. Technology assessment and quality of life. Amsterdam: Elsevier Scientific.

WHITAKER, D.; ARCHER, L. \& HICKS, L. 1998. Working in children's homes: Challenges and complexities. Chichester: John Wiley \& Sons. 